\title{
Do social networks and technological capabilities help knowledge management?
}

\author{
Encarnación García Sánchez ${ }^{1 *}$, Víctor Jesús García Morales ${ }^{1}$, Rodrigo Martín-Rojas ${ }^{1}$
}

\begin{abstract}
Dynamic capabilities are currently becoming an important extension of the theory of resources and capabilities that enables companies to adapt better in the current competitive environment. This paper examines how knowledge management, a dynamic function related to management or administration of a set of knowledge flows, develops thanks to the greater dynamism of social networks. It then shows how this relationship is especially strengthened by different technological capabilities. To achieve these goals, the paper examines the main tools that permit companies to develop an ability to achieve competitive advantage relative to the technological capabilities of managers and workers, social networks and knowledge management.
\end{abstract}

Keywords: Social networks; Top management support for technology; Technological skills; Distinctive technological skills; Knowledge management.

Submitted: May $11^{\text {th }} 2017 /$ Approved: December $22^{\text {nd }} 2017$

\section{Introducción}

The current environment is characterized by continuous change that is more rapid and less predictable than before. The organization's response to such change will be decisive for its future development. An inappropriate, incomplete or slow response will damage the firm and its ability to adapt and learn (Hanssen-Bauer \& Snow, 1996). It is thus of vital importance that the firm be up to date with what is happening beyond its boundaries, and increasingly clear that the firm must stimulate learning and manage the resulting knowledge (Fernandez Perez et al., 2012). We therefore stress that the strategic activity of the $21^{\text {st }}$-century firm lies not in its products and services, but rather in the continuous learning of its human resources to achieve continuous improvement of workers' competencies, knowledge and abilities, as human resources are the foundation of competitive advantage (Fernandez Perez et al., 2011; Garcia, 1998; Maurer, 2001).

In addition, organizations take strategic decisions in competitive global environments in which the development of technology and technological processes are important for maintaining levels of competitiveness (Jones et al., 2000).

Technology is a strategic mechanism for improving cooperation, communication, and exchange of information and knowledge through the presence and proper use of tools or assets that foster knowledge. With technology, information flows faster and is propagated more easily throughout the organization. This study thus analyses the concept of technology through the different key technological means in the current context (Martin-Rojas et al., 2011):

A) Top management support for technology (TMS) shows the development of a work environment that supports systems of knowledge and information management. TMS can, in turn, provide the appropriate funds and resources, encourage teams and help to overcome problems, fostering multi-functional cooperation, knowledge and communication (Garcia et al., 2008).
B) Technological abilities can be understood as one of the "dimensions that distinguishes and provides the knowledge set needed to enable an essential capability" (Leonard-Barton, 1992, p. 113). This dimension of abilities spans both the specific techniques of the firm and scientific knowledge, providing the foundation for the firm's competencies and for sustainable competitive advantage in a specific firm (Teece et al., 1997).

C) Distinctive technological skills (TDC) represent "the organization's experience in mobilizing diverse scientific and technical resources through a series of routines and procedures that enable the development and design of new products and production processes" (Real et al., 2006, p. 508).

TMS, the development of technological abilities and the fostering of TDCs play an important role in accessing information and seeking internal and external knowledge sources (Jiménez et al., 2011).

In addition to technology, one must take social networks into account. A social network can perform a key role in improving the organization's capabilities, particularly in knowledge management (Dyer \& Nobeoka, 2000; Liebeskind et al., 1996.). Social networks constitute a basic element for acquiring information and knowledge from the outside, to be disseminated within the organization (Fernandez Perez et al., 2012).

\section{Theoretical Framework}

This research focuses on tools within the reach of the organization that permit it to achieve competitive advantage related to technological variables, social networks and knowledge management. It does so by using the theoretical framework of the resource-based view (Barney, 1991) and the theory of dynamic capabilities (Eisenhardt \& Martin, 2000; Teece et al., 1997).

With the resource-based view, one must take into account two fundamental issues. First, resources are distributed heterogeneously among

(1) Business Administration Department at Granada University (Spain).

*Corresponding author: encags@ugr.es 
different firms; second, resources persist over time. That is, organizations possess a set of resources and capabilities that are more or less valuable, which permit them to obtain a sustainable competitive advantage. The resources and capabilities must therefore be valuable, rare, difficult to imitate and difficult to replace (Barney, 1991).

Despite the valuable contribution of the resource-based view, various studies have criticized its static vision, indicating the need to complement it with the dynamic capabilities perspective.

Organizations are conscious that the conditions that surround them are those of changing and turbulent environments where competition is very strong. Factors change with increasing speed, technological advances cause more rapid innovations, etc. In the face of such circumstances, it is quite difficult for organizations to maintain the competitive advantage achieved in the past unless they adapt to the changes. The theory of dynamic capabilities is grounded in the idea that only firms that can develop dynamic capabilities will be able to generate sustainable competitive advantage (Teece et al., 1997).

According to this theoretical framework, and taking into account the definitions of technological variables studied, a dynamic integrating capability can be assimilated that enables reconfiguration of internal competencies and promotion of the organizational changed needed based on the demands of the environment. Social networks, in turn, can be analysed as "the links that connect a specific set of people or social actors" (Seibert et al., 2001, p. 220). Finally, we find an abundant literature on knowledge management that defines it as a basic pillar for development of dynamic capabilities and a key strategic factor supporting the search for collaborative learning and communication (Jiménez et al., 2011). Organizations thus need knowledge management to adapt to the changes in the environment and to respond properly to existing uncertainty. For this reason, knowledge management is considered as a dynamic capability for the organization (Zahra \& George, 2002).

\section{Social Networks and Knowledge Management}

As indicated above, social networks can be analysed as the links that connect a specific set of people or social actors (Seibert et al., 2001). Research on social networks suggests that the links in these networks enable collaborative work and exchange of ideas, information and knowledge among the members who compose them (Fernandez Perez et al., 2012; Fliaster \& Spiess, 2008), as well as generation of solutions and identification of problems and opportunities (Kijkuit \& Van Den Ende, 2007). As the largest social networks are efficient for accessing a large quantity of new information and knowledge (Burt, 1992), many authors stress the importance of mechanisms for organizational integration that permit assimilation of knowledge from outside the organization so that this knowledge can be transformed and exploited (Cohen \& Levinthal, 1990).

Knowledge management, in turn, is defined as identification and exploitation of the collective knowledge of an organization to help the entity to compete (Alavi \& Leidner, 2001). In recent years, organizations' interest in knowledge management has grown, as it represents a means of obtaining greater benefits and a source of sustainable competitive advantage. Knowledge management encompasses a set of activities that enable the organization to create value from the knowledge assets the firm possesses (Alavi \& Leidner, 2001).

Knowledge management thus involves the transformation and management of all knowledge flows and is responsible for the administration of all intangible assets that contribute value to the organization in achieving essential and distinctive capabilities and competencies (Fernandez Perez et al., 2011). In conclusion, one could say that knowledge management is a dynamic function related to the management or administration of a set of knowledge flows (Bueno, 1999).

The literature includes various studies that argue the benefits gained fromsocial networks (e.g., Burt, 1992; Fernandez Perez et al., 2012; Kijkuit \& Van Den Ende, 2007; Obstfeld, 2005; Powell, 1990; Zucker, 1991). And the presence of these contacts can contribute very significantly. First, one can access extensive sources of information and improve the levels of quality, relevance, and opportunity of this information. Social networks are more efficient in providing valuable information on markets or even internal hierarchical structure, where communication difficulties can occur (Powell, 1990). Second, they provide solidarity and trust, since having strong shared norms and beliefs reduces the need for control of information obtained and provides incentive for the establishment of knowledge flows. Despite these results, social networks can generate risks that in some cases outweigh the benefits they can yield. The first risk comes from the type of information accessible, since obtaining this information requires considerable investment in establishing and maintaining these relationships. Second, as to the risks of solidarity and trust, the presence of strong solidarity among the members of a group can limit flows of new ideas and lead to a closed mentality, even reducing the group's entrepreneurial activity, growth and development (Fernandez Perez et al., 2011).

A social network can thus play a key role in improving the organization's capabilities, especially in knowledge management (Dyer \& Nobeoka, 2000; Liebeskind et al., 1996). As social networks constitute a basic element for acquisition of information and knowledge from outside the organization, which can then be disseminated within the organization, we can affirm that knowledge management and social networks are closely related (Fernandez Perez et al., 2012).

\section{Technological variables, Social Networks and Knowledge Management}

Technological variables play a crucial role in knowledge management, due to their strategic capability to support communication and the search for knowledge, and to stimulate collaborative learning (Hargadon, 1998; Martin-Rojas et al., 2013). Among these technological assets, support for technology management, technological abilities and distinctive technological capabilities fosters creation of an organizational culture that seeks to identify opportunities and generate new ideas, knowledge and concepts (Garcia-Sanchez et al., 2016). 
Such creation and acquisition of knowledge can come from exploring the environment, through technological media or interaction with agents, through technology systems or networks. By means of interactions with others, firms can access external knowledge and combine it with existing knowledge. These relationships between organizations include the contacts that a firm may have with external organizations, including customers, suppliers, investors, the government, institutions, etc. (Dyer \& Singh, 1998; Larson, 1992). Luo (2001) indicates that network ties between local Chinese managers and foreign managers with different culture and diverse experience and management abilities increases the managers' willingness to develop new knowledge. The knowledge management process thus requires collaboration among network members to carry out a specific task in a specific time period (Powell et al., 1996). Along the same lines, Dyer and Nobeoka (2000) find that learning teams in networks of Toyota suppliers contribute to the articulation of new practices by increasing trust and capabilities to advance together in a new direction.

Further, technological variables provide key support for the exchange and exploitation of knowledge. Intranet, extranet, virtual private networks (VPN) and Ethernet, for example, combine technologies and services, enable construction of a digital environment in which new knowledge is constantly created, and permit rapid dissemination of this knowledge and processes and their exploitation throughout the organization (Garcia-Sanchez et al., 2015). Organizations that invest in technological assets to support knowledge exchange among the members of virtual groups or teams contribute not only to obtaining greater yield from the knowledge but also to developing the organization's knowledge management capability (Young-Choi et al., 2010). Technological variables enable members of work teams to interact with each other, not only to transform and transfer knowledge, but also to solve complex problems and invent new solutions (Boland \& Tenkasi, 1995; Martin-Rojas et al., 2013). A positive relationship exists among technological variables, social networks and knowledge management, since firms must assimilate this knowledge in order to learn from external relationships, recognize the new utility of information and knowledge, and thus apply it to commercial ends.

\section{Conclusions}

In recent years, the business environment has become more competitive, due to globalization, rapid technological changes and greater sophistication in the behaviour of customers and employees (Jiménez et al., 2011). To face these changes, firms innovate through a process of continuous learning through which they generate new competencies and knowledge (Md Zahidul et al., 2009). Today, knowledge management is a necessity rather than an option if firms wish to maintain a competitive advantage (Fernandez Perez \& Gutierrez-Gutierrez, 2013).

Networks of social relationships are an important resource for organizations. Since they are what link us to other groups, they can condition the firm's action to a great extent. Through networks, the organization acquires information and knowledge, fundamental resources for competitiveness and survival in today's knowledge society. A greater number of contacts generates a greater number of perspectives. This diversity of views contributes to knowing more ideas and creating new ones (Burt, 1992; Obstfeld, 2005), although it also requires greater involvement of the organization's administrators in management of these ideas, due to the size and complexity involved.

It is thus important, even crucial, that organizations invest in technological assets. Managers must invest continuously and substantially in developing knowledge management and learning in the organization and create incentives for the creation and development of a social network adequate to the organization's interests or competitive needs. It is crucial to have people who are trained and capable of accessing new and relevant information and knowledge, thereby contributing to improvements in the firm's performance (Collins \& Clark, 2003; Martin-Rojas et al., 2013).

As a result, organizations must foster the development of environments characterized by collaborative work and trust, in which each employee can edit content and documents, and interact with other members of the organization at any moment from any place. Organizations must invest in tools and social networks to design, modify and execute work flows with inter-hierarchical lines of communication among the organization's members. Such flows will enable free circulation of ideas from different processes in the firm or in advanced search engines to capture and apply external knowledge and stimulate innovation, thereby increasing the organization's performance.

\section{References}

Alavi, M., \& Leidner, D. E. (2001). Review: Knowledge management and knowledge management systems: Conceptual foundations and research issues. MIS Quarterly, 25(1), 107-136.

Boland, R. J. \& Tenkasi, R. V. (1995). Perspective making and perspective taking in communities of knowing. Organization Science, 6(4), 350-372.

Bueno Campos, E. (1999) Gestión del conocimiento, aprendizaje y capital intelectual, Curso de Desarrollo de Directivos. Instituto Universitario Euroforum Escorial. San Lorenzo de el Escorial.

Burt, R. S. (1992). Structural holes: The social structure of competition. Cambridge, MA. Harvard University Press.

Burt, R. S. (2000). The network structure of social capital. R. I. Sutton and B. M Straw (Eds.). Research in organizational behaviour, 22, 345 423. JAI Press. Greenwich, CT.

Cohen, W. \& Levinthal, D. (1990). Absorptive capacity: A new perspective on learning and innovation. Administrative Science Quarterly, 35(1), 128-152.

Collins, C. J. \& Clark, K. D. (2003). Strategic human resource practices, top management team social networks, and firm performance: The role of human resource practices in creating organizational competitive advantage. Academy of Management Journal, 46(6), 740-751. 
Dyer, J. H. \& Nobeoka, K. (2000). Creating and managing a highperformance knowledge-sharing network: The Toyota case. Strategic Management Journal, 21(3), 345-367.

Dyer, J. H. \& Singh, H. (1998). The relational view: Cooperative strategy and sources of interorganizational competitive advantage. Academy of Management Review, 23(4), 660-679.

Fernandez-Perez, V., Garcia-Morales, V. J. \& Bustinza-Sanchez, O. F. (2012). The effects of CEOs' social networks on organizational performance through knowledge and strategic flexibility. Personnel Review, 41(6), 777-812.

Fernandez-Perez, V. \& Gutiérrez-Gutiérrez, L. (2013). External managerial networks, strategic flexibility and organizational learning: A comparative study between Non-QM, ISO and TQM firms. Total Quality Management \& Business Excellence, 24(3/4), 243-258.

Fernandez Perez, V., Martin Rojas, R. \& Garcia Sanchez, E. (2011). Redes sociales empresariales: ¿Una oportunidad o una pérdida de tiempo en la sociedad del conocimiento? Gestión Joven, 7, 38-50.

Fliaster, A. \& Spiess, J. (2008). Knowledge mobilization through social ties: The cost-benefit analysis. Schmalenbach Business Review, 60(1), 99-117.

Garcia Morales, V. J., Llorens Montes, F. J. \& Verdu Jover, A. J. (2008). The effects of transformational leadership on organizational performance through knowledge and innovation. British Journal of Management, 19, 299-319.

Garcia Palomero, I. (1998). Las organizaciones cualificantes. Capital Humano, 108, 32-36.

Garcia-Sanchez, E., Garcia-Morales, V. J. \& Bolivar-Ramos, M. T. (2015). The influence of top management support for ICTs on organisational performance through knowledge acquisition, transfer, and utilisation. Review of Managerial Science, in press.

Garcia-Sanchez, E., Martin-Rojas, R. \& Fernandez-Perez, V. (2016). Influence of top management support and technological assets in knowledge management. DYNA Management, 4(1), 20-29. DOI: http://dx.doi.org/10.6036/MN7783

Hanssen-Bauer, J. \& Snow, C. C. (1996). Responding to hypercompetition: The structure and processes of a regional learning network organization. Organization Science, 7, 413-427.

Hargadon, A. B. (1998). Firms as knowledge brokers: Lessons in pursuing continuous innovation. California Management Review, 40(3), 209-227.

Jiménez Barrionuevo, M. M., Garcia Morales, V. J. \& Molina, L. M. (2011). Validation of an instrument to measure absorptive capacity. Technovation, 31(5-6): 190-202.
Jones, G. K., Lanctot, A. Jr. \& Teegen, H. J. (2000). Determinants and performance impacts of external technology acquisition. Journal of Business Venturing, 16, 255-283.

Kijkuit, B. \& Van Den Ende, J. (2007). The organizational life of an idea: Integrating social network, creativity and decision-making perspectives. Journal of Management Studies, 44(6), 863-882.

Larson, A. (1992). Network dyads in entrepreneurial settings: A study of governance of exchange relations. Administrative Science Quarterly, 37(1), 76-104.

Leonard-Barton, D. (1992). Core capabilities and core rigidities: A paradox in managing new product development. Strategic Management Journal, 13, 111-125.

Liebeskind, J. P., Oliver, A. L., Zucker, L. \& Brewer, M. (1996). Social networks, learning, and flexibility: Sourcing scientific knowledge in new biotechnology firms. Organization Science, 7(4), 428-443.

Luo Y. (2001). Antecedents and consequences of personal attachment in cross-cultural cooperative ventures. Administrative Science Quarterly, 46, 177-201.

Martin Rojas R., Garcia Morales, V. J. \& Bolivar Ramos, M. T. (2013). Influence of technological support, skills and competencies, and learning on corporate entrepreneurship in European technology firms. Technovation, 33, 417-430.

Martin Rojas, R., Garcia Morales, V. J. \& Garcia Sanchez, E. (2011). The influence on corporate entrepreneurship of technological variables. Industrial Management and Data Systems, 11(7), 984-1005.

Maurer, T. J. (2001). Career-relevant learning and development, worker age, and beliefs about self-efficacy for development. Journal of Management, 27, 123-140.

Md Zahidul, J. A., Doshi, H. M. \& Zainal, A. A. (2009). Team learning, top management support and new product development success. International Journal of Managing Projects in Business, 2(2), 238-260.

Obstfeld, D. (2005). Social networks, the tertius lungens orientation, and involvement in innovation. Administrative Science Quarterly, 50, 100-130.

Powell, W. (1990). Neither market nor hierarchy: Network forms of organization. Research in Organizational Behaviour, 12, 295-336.

Powell, W., Koput, K. \& Smith-Doerr, L. (1996). Interorganizational collaboration and the locus of innovation: Networks of learning in biotechnology. Administrative Science Quarterly, 41, 116-145.

Real, J. C., Leal, A. \& Roldan, J. L. (2006). Information technology as a determinant of organizational learning and technological distinctive competencies. Industrial Marketing Management, 35, 505-521. 
Seibert, S. E., Kraimer, M. L. \& Liden, R. C. (2001). A social capital theory of career success. Academy of Management Journal, 44(2), 219-237.

Teece, D. J., Pisano, G. \& Shuen, A. (1997). Dynamic capabilities and strategic management. Strategic Management Journal, 18(7), 509533.

Young-Choi, S., Lee, H. \& Yoo, Y. (2010). The impact of information technology and transactive memory systems on knowledge sharing, application, and team performance: A field study. Management Information Systems, 34(4), 833-854.

Zahra, S. A. \& George, G. (2002). Absorptive capacity: A review, reconceptualization, and extension. Academy of Management Review, 27 (2), 185-203.

Zucker, L. (1991). Markets for bureaucratic authority and control: Information quality in professions and services. Research in the Sociology of Organization, 8, 157-190.

\section{Biographical Notes}

Encarnacion Garcia-Sanchez is Assistant Professor of Management and Business Economy at Granada University, in the South of Spain. She current research interests include knowledge management, organisational learning, information technologies, technological distinctive competencies, corporate entrepreneurship and organisational performance. She has published in Industrial Management \& Data System, Journal of Engineering and Technology Management.

Víctor J. García Morales is Professor of Management, Business Economy and Environmental Issues in the Business Administration Department at Granada University (Spain). He received his $\mathrm{PhD}$ in Organisational Learning and Knowledge Management at Granada University. His current research interests include organisational learning, innovation, new technologies and corporate entrepreneurship and organisational performance. He has published in some journals such as: British Journal of Management, Technovation, Industrial Management \& Data Systems, Production Planning and Control, International Journal of Human Resource Management, Teaching and Teacher Education, International Journal of Manpower.

Rodrigo Martín Rojas Assistant Professor of Management and Business Economy at Granada University, in the South of Spain. His current research interests include personal IT innovativeness, high technology based firms, new technology, Information Technologies, technological distinctive competencies, tourism organisations, family business, corporate entrepreneurship and organisational performance. Recently, he has published in journals such as Industrial Management \& Data Systems, Engineering Economics, Journal of Knowledge Management, International Journal of the Academy of Organizational Behavior Management or in books such as Handbook of Sustainable Management. 